\title{
Association between COVID-19 and psychological disorders with possible mechanisms
}

\author{
Sworadip CHOWDHURY ${ }^{1}$ (D), Hoimonti DEBI ${ }^{1}$ (D), Mohammad Tohidul AMIN 1 (D), Sujan BANIK ${ }^{1,2}$ (D), \\ Fahad HUSSAIN 1 (D), Mohammad Salim HOSSAIN 1 * iD \\ 1 Department of Pharmacy, Noakhali Science and Technology University, Noakhali-3814, Bangladesh. \\ 2 Laboratory of Biopharmacy, School of Pharmaceutical Sciences, University of Shizuoka, 52-1 Yada, Suruga-ku, \\ Shizuoka 422-8526, Japan. \\ * Corresponding Author. E-mail: pharmasalim@yahoo.com (M.S.H); Tel. +88-017-1120 0410.
}

Received: 10 April 2021 / Revised: 24 July 2021/ Accepted: 25 July 2021

ABSTRACT: The current coronavirus pandemic is one of the most wrecking occasions in ongoing history, and it has an impact on mental health, especially in sleep disorder and anxiety. This review aimed to find an association between COVID-19 and psychological disorders like sleep disorder and anxiety by exploring its influential factors. COVID-19 patient has greater susceptibility to having anxiety and sleep disorder-related complications including post-traumatic stress disorder, obsessive-compulsive disorder (OCD), obstructive sleep apnea by infecting severe acute respiratory syndrome coronavirus 2 (SARS-CoV-2) to the central nervous system through the olfactory lobe. Although the mechanism of COVID-19 induced sleep disorder and anxiety-related complications have not been reported yet, the investigated data suggested that sleep disorder and anxiety-related complications are arising due to increasing cortisol, norepinephrine levels in the blood and decreasing glucocorticoid receptor signaling. Further examination and clinical studies are critically required to investigate the influential factors of COVID-19 patients' susceptibility to sleep disorder, anxiety for affirming speculation, and better treatment.

KEYWORDS: Anxiety; biological marker; COVID-19; SARS-CoV-2; sleep disorder.

\section{INTRODUCTION}

Coronavirus disease 2019 (COVID-19) outbreak during November 2019 grew up in Wuhan, China, which caused global attention [1]. As of November 5, 2020, 47,362,304 confirmed cases around the world and 1,211,986 death reported in 218 countries, according to the World Health Organization (WHO) [2]. There was an immense strain on the medical staff, including a high risk of infection, inflammation through the arachidonic acid cascade, alienation, patient with negative emotions, and overwork. The extreme condition triggers mental health issues such as anxiety, depressive symptoms, insomnia, apprehension, and the mental health of adult care staff has gained widespread attention during the COVID-19 outbreak [3,4].

A research group examined human value by evaluating the Personal Social Capital Scale 16 (PSCI-16) and sleep patterns in self-isolated adolescents during the pandemic of COVID-19 [5]. The investigation found that stress and reduced sleep quality are associated with anxiety, and the combination of stress and anxiety decreased the positive impacts of social resources on sleep habits. The research also found that isolated individuals had high levels of anxiety and stress. In China, scientists likewise inspected a condition of emotional wellness of about 1250 human services experts treated as coronavirus patients [6]. They reported that $50.4 \%$ of members effected by depression, $44.6 \%$ anxiety, $34.0 \%$ sleep deprivation, and $71.5 \%$ distress. Anxiety, depression, and suicidal behavior are associated with sleep disturbances. Sleep disruption triggers the stand-alone risk factor for suicidal thoughts, suicide attempts, and suicide fatality [7]. Considering the above facts, the current study was undertaken to view the association of severe acute respiratory syndrome coronavirus 2 (SARS-CoV-2) infection in individuals with anxiety, sleep disorder, and related complications.

\section{COVID-19 AND ANXIETY}

Anxiety, a psychological disorder, can induce a sequence of physiological events and cause immunity to decline [8]. While significant attention has been paid to initiatives to identify people with the coronavirus

How to cite this article: Chowdhury S, Debi H, Amin MT, Banik S, Hussain F, Hossain MS. Association between COVID-19 and psychological disorders with possible mechanisms. J Res Pharm. 2021; 25(6): 799-806. 
infection, recognizing people's mental health needs affected by this pandemic has been overlooked relatively [3]. For instance, in a recent large-scale survey on Chinese medical workers who are highly susceptible to infection with coronavirus, the incidence of traumatic stress at an unprecedented $73.4 \%$, depression at $50.7 \%$, pervasive anxiety at $44.7 \%$, and insomnia at $36.1 \%$ [9]. Patients with confirmed or suspected COVID-19 may be fearful of the effects of a potentially lethal new virus infection, and those in the quarantine may feel fatigued, lonely, and anger. The infection symptoms include fever, hypoxia, cough, and adverse treatment effects such as corticosteroid-induced insomnia, which may worsen anxiety and mental distress. Mandatory communication monitoring and 14-day quarantine, which are part of the response to the SARS-CoV-2 pneumonia outbreak, may increase patient anxiety and guilt about the effect of infection, quarantine, and stigma to family and friends of their own [3]. Recently, a descriptive cross-sectional longitudinal analysis was performed on 144 patients with confirmed COVID-19 who admitted to Huoshenshan Hospital (Wuhan, China) during the COVID-19 epidemic from February 23 to March 13, 2020. The study data revealed that 50 $(34.72 \%)$ and $31(28.47 \%)$ participants had a sign of anxiety and depression, respectively, regarding the Hospital anxiety and depression scale (HADS). Another study was used to assess the psychological effects of COVID-19 on a total of 2737 healthcare workers by using a two-dimensional code shared online between March 4 and March 9, 2020, and this investigation indicates about 61.6 percent of the respondents reported sleep disturbance, 22.6 percent experienced anxiety, and 35 percent exhibited depression symptoms [10]. They also revealed that less social care was associated with more anxious and depressive symptoms [11]. COVID19 had a median survival of 36 days for those with a base concentration of cortisol equal to or below 744 nmol/L, (268 patients; $67 \%$ ), [95\% Cl 24 not established]; while the COVID-19 had a median survival of 15 days with cortisol of more than $744 \mathrm{nmol} / \mathrm{L}$ (135\% of patients; 33\% of patients) [12].

\section{POSSIBLE MECHANISM PATHWAY OF COVID-19 AND ANXIETY}

\subsection{ACE2 induce anxiety in COVID-19}

The SARS-CoV-2 has stronger pathogenicity and transmissibility than SARS-CoV and MERS-CoV because SARS-CoV-2 has a substantial binding capacity with angiotensin-converting enzyme 2 (ACE2) [13]. ACE2 is a cardiovascular protective factor found in various organs, including the nervous system and skeletal muscles, which play a key role in regulating blood pressure and mechanisms to combat atherosclerosis [14]. Meanwhile, ACE2 is also a significant target for different $\mathrm{CoV}$ and strains of influenza [15]. The SARS-CoV-2 spike protein can interact with ACE2 expressed in capillary endothelium binding to ACE2 receptors; the virus can also weaken the blood-brain barrier (BBB) and penetrate the CNS by targeting the blood vessels [16]. Under this situation, the stressor-dependent corticotrophin-releasing hormone (CRH) in susceptible individuals release from the hypothalamic paraventricular nucleus (PVN) neurons. The hyperactivity of the hypothalamic-pituitary-adrenal (HPA) axis is further triggered by binding to the CRH receptors in the anterior pituitary gland to induce the production of the adrenocorticotropic hormone (ACTH) [17]. ACTH is transmitted through the blood to the adrenal cortex of the adrenal gland, where it activates the biosynthesis of a glucocorticoid such as cortisol [18, 19], which was responsible for stress-induced anxiety. A high concentration of cortisol was also involved with increased morbidity and decreased median survival [12]. In this situation, the HPA axis may not produce a sufficient amount of corticosteroids in critically ill patients, leading to illness-related corticosteroid insufficiency [18].

\subsection{Glucocorticoid receptor (GR) resistance and FKBP5 gene induced anxiety with COVID-19}

Neurotropic coronavirus is generally assumed to enter the CNS through olfactory neurons and then spread to other sites in the brain or reach the brain from the bloodstream [20]. The stress protein FKBP5 was initially introduced to biological psychiatry due to its effect on the glucocorticoid receptor (GR) [21, 22]. Several lines of evidence suggest that a crucial functional regulator of the GR complex is the FK506 binding protein 51 , a $51 \mathrm{kDa}$. These proteins are encoded by the gene FKBP5, located on the short arm of human chromosome 6 (chromosome 6p21.31) [23, 24]. FKBP5 binds to hsp90 through a TPR (tetratricopeptide repeat protein)domain during maturation of the GR complex that serves as a docking station for some different cochaperones. The receptor complex in this structure has a lower affinity to cortisol [25]. FKBP5 may also encourage the nuclear translocation of the GR's non-active beta-isoform, thereby reducing overall GR signaling [26]. Impaired GR signaling leading to impaired negative feedback control, and thus, partial glucocorticoid tolerance tends to be one of the most significant biological abnormalities in mood disorder [27]. Higher levels of anxiety among females are given by a form of halogen vulnerability, including short alleles 
of seven common FKBP5 SNPs (rs9470080, rs3800373, rs7748265, rs1360780, rs9296158, rs9394309, and rs4713916) [28] (Figure 1).

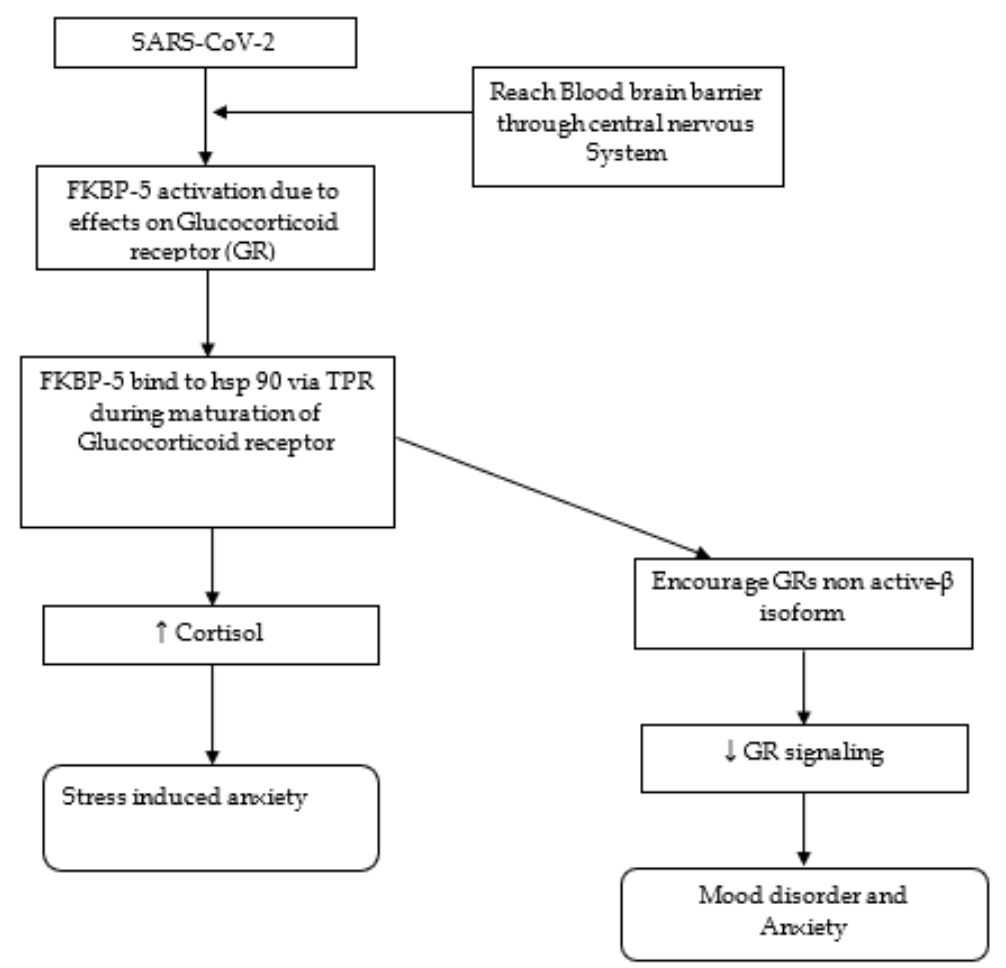

Figure 1. Possible mechanism pathway of anxiety after invading SARS-CoV-2.

\section{COVID-19 AND SLEEP DISORDER}

Coronavirus affects the respiratory system and affects the central nervous system (CNS), which is detected by virus availability in the cerebrospinal fluid in COVID-19 patients [29, 30]. COVID-19 is possibly related to interrupted neurological manifestations, and patients with multiple general symptoms were most commonly recognize [31]. It commonly occurred at any time during infection. Growing evidence indicates that SARS-CoV-2 can inflict CNS, showing that 214 hospitalized patients have acute brain disorders, consciously disturbing and muscle damage, and neurological manifestations, of 36.5 percent in Wuhan, China found induction of SARS-CoV-2 [29]. Furthermore, cardiovascular complications such as hypertension, heart failure, coronary artery disease, cerebrovascular diseases, diabetes mellitus, and obesity are also risk factors for severe outcomes in COVID-19 are commonly seen in sleep disorder patients [32, 33]. However, the mechanism associated between COVID-19 and sleep disorder has not been reported yet.

\section{POSSIBLE MECHANISM PATHWAY OF SLEEP DISORDER AFTER INVADING SARS-CoV-2}

SARS-CoV-2 is a coronaviridae enveloped RNA virus, having 29,891 nucleotides in size encoded with 9860 amino acids [34]. A study demonstrates that ACE-2 is expressed abound in human organs and CNS and acts as a target of SARS-CoV-2 infection with transmembrane serine protease -2 (TMPRSS2) [35, 36]. The SARS-CoV-2 invasion is caused by the binding of host cells ACE-2 receptors, leading to infected host cells and spreading [13]. After crossing, the BBB virus gains entry to the CNS and affects the paraventricular nucleus $(\mathrm{PVN})$ [37]. Corticotropin-releasing (CRH) hormone secreted from PVN, causing the hyperactivation of the HPA axis. CRH receptors in the anterior pituitary stimulate to release of ACTH into the blood. ACTH operates on the adrenal cortex, generates and releases cortisol into the blood, and maintains body-wide homeostasis $[17,38-40]$. Increasing cortisol levels in the blood cause sleep disorder, including low sleep quality and shorter sleep duration [41] (Fig. 2). CRH additionally actuates the locus ceruleus (LC), which can use norepinephrine (NE) and creates additional incitement of the PVN, and that prompts the arrival of CRH. Elevated NE and CRH levels lead to implicated sleep disorders, including primary insomnia [42, 43]. HPA hyperactivity harms sleep, including the fragmentation of sleep, slow-wave sleep, and shortened sleep time, leading to a worsening sleeping cycle [43] (Figure 2). 


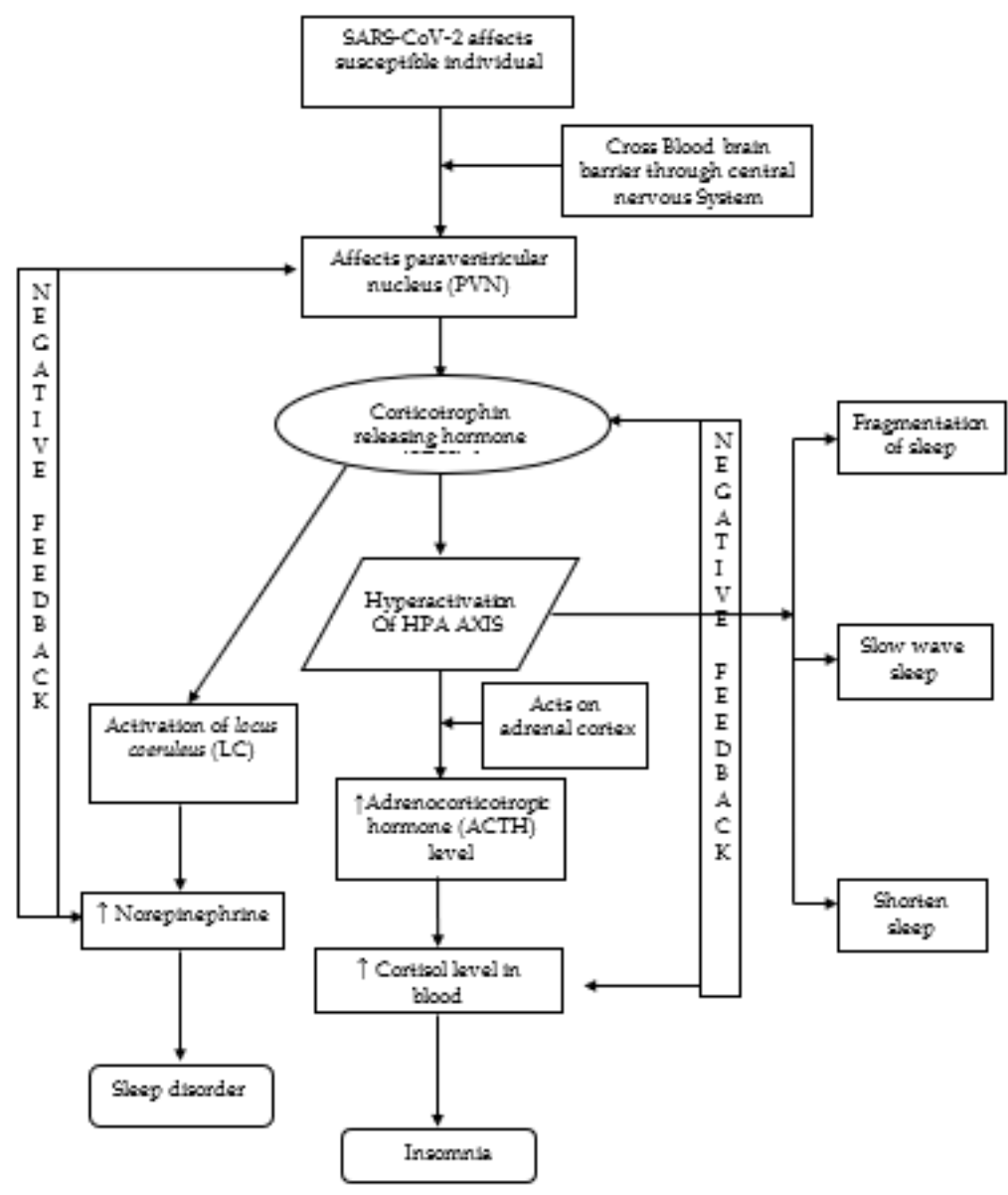

Figure 2. Possible mechanism pathway of sleep disorder after invading SARS-CoV-2.

The COVID-19 societal disaster has led to prolonged stress, anxiousness, and sleep deprivation, which shall emerge as a difficulty of systemic scientific analysis. These apparent elements may additionally harm the immunity and peoples' potential to avert COVID-19 as different infections. Deprivation of sleep may have a double role in immune function [44]. Short sleep can harm immunity, while insufficient sleep can also lead to hormones [45]. There is an increase in pro-inflammatory levels of Interleukin- 6 (IL-6) and TNF- $\alpha$ receptors and decreased levels of anti-inflammatory Interleukin- 10 (IL-10) [45-47]. It is not surprising that multiple diseases with chronic inflammation such as metabolic, cardiovascular, cognitive, and other disorders are associated with sleep deprivation [48] (Figure 3).

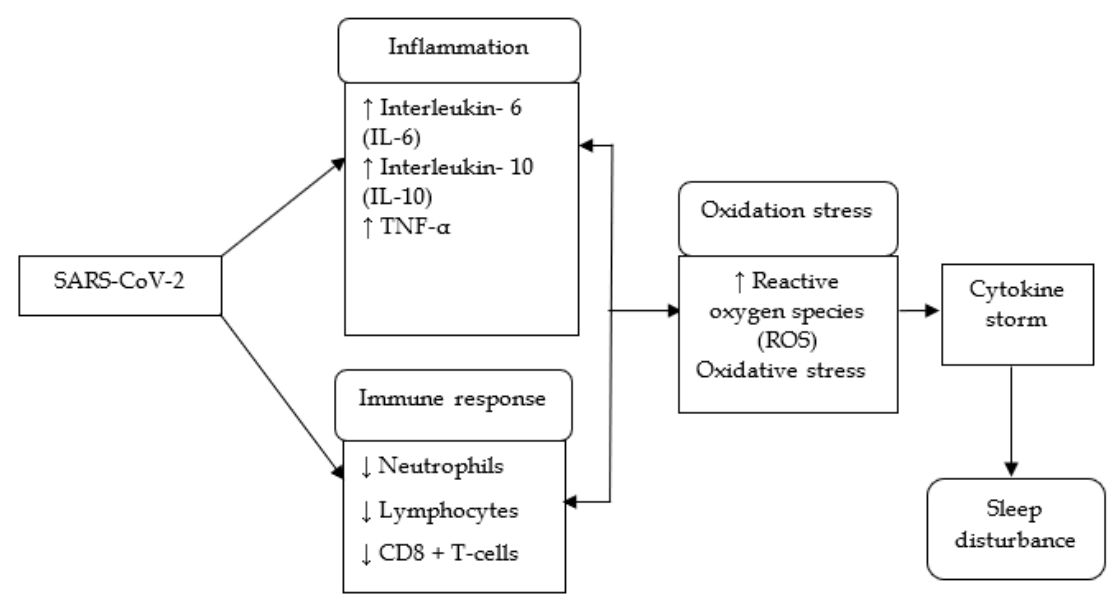

Figure 3. SARS-CoV-2 infects individuals and elevates inflammation, suppressed immune response, and excessive oxidation stress, leading to cytokine storm activation, which induced sleep disturbance. 
Different impacts of lack of sleep included diminished lymphocyte multiplication following 48-hours and decreased phagocyte action after 72 hours of lack of sleep [49]. In one investigation, some healthy volunteers who sleep less than 6 hours for seven days had reduced neutrophil phagocytosis levels, decreased NADPH oxidase levels, and fewer CD4+T cells. These are crucial for anti-infective protection and proper immunization response. Even after one week of restored sleep, the NADPH oxidase level remained reduced, suggesting long-lasting sleep deprivation effects.[50]. Besides, sleep-deprived people immunized against the influenza-A virus will reduce the number of antibodies relative to those immunized without insomnia [51]. After one night, people with reduced sleep cause a lower immunization and antibody level against the hepatitis A virus [52]. Suppression of the system leading to sepsis and microbial infection was recorded in sleep-deprived rats [53]. Oxidative stress reduces the enzyme's antioxidant activity due to sleep deprivation [54], [55]. Therefore, a long-term lack of sleep results in worsening immune functions and disrupting barrier mechanisms by suppressing the phagocytosis, falling proliferation, and leukocyte activity, specially CD4+T cells. On the other hand, elevate T-suppressors, oxidative stress, and pro-inflammatory mounting. So there is greater susceptibility to infection by infectious diseases with sleep deprivation [56] (Figure 3).

\section{ANXIETY AND SLEEP DISORDER RELATED COMPLICATION WITH COVID-19}

\subsection{Post-traumatic stress disorder}

Psychological factors that may increase the risk of suicide among COVID-19 patients include hearing about their diagnosis, anxiety, depression related to disease symptoms, and stress related to hospitalization and care in the hospital [7]. Individuals requiring admission to an intensive care unit (ICU) are particularly at high risk of developing post-traumatic stress disorder, depression, and cognitive impairment [57, 58]. A recent analysis of the impact of COVID-19 on the CNS indicates that about $25 \%$ of patients have neurological manifestations [30]. A Chinese study found that 96.2 percent of COVID-19 patients had severe symptoms of post-traumatic stress.

\subsection{Obsessive-compulsive disorder (OCD)}

Broader research indicates that people with OCD may be more vulnerable to the psychological danger of viruses and germs due to an already unstable and incoherent identity [59]. In particular, the spike of virus anxiety fuels existing obsessive contamination fears in some people with $O C D$ and further triggers harmful compulsive action.

\subsection{Obstructive sleep apnea (OSA)}

Obstructive sleep apnea is one type of sleep disorder that occurs due to upper airway resistance and interruption of the airflow accompanied by increased respiratory effort. In OSA, myocardial tissue is affected due to the increase of catecholamines, leading to elevated blood pressure and tachycardia. Consequently, it causes oxygen demand and results from myocardial ischemia, facilitating both atrial and ventricular arrhythmias [60]. In most of the COVID-19 patients having cardiovascular manifestation including myocardial injury (7.2\%) (Involving ACE-2 signaling pathway), systemic inflammation altered (8.7\%), myocardial demand-supply balance (leading to acute myocardial ischemia) $(16.7 \%)$, and increasing the vulnerability to various tachyarrhythmias. Besides, COVID-19 patients treated with several drugs, including chloroquine and hydroxychloroquine, contribute to adverse outcomes in arrhythmias, especially in the presence of long-QT syndrome or other conduction defects [61]. As a result, patients with OSA have a greater risk of being infected by SARS-CoV-2. If it occurs, it will lead to a higher incidence of cardiovascular incidences such as arrhythmias, cardiac ischemia, and hypercoagulability states, leading to an unfavorable clinical progression $[62,63]$.

\section{CONCLUSION}

In this study, we highlight the association between psychological disorders with SARS-CoV-2 infections. The development of anxiety-related disorders such as post-traumatic stress disorder (PTSD), OCD, generalized anxiety disorder, panic disorder, and sleep-related disorders such as insomnia, sleep apnea, and narcolepsy are significant concerns for COVID-19 patients. Symptoms of the nervous system are considered a possible predictor of poor prognosis. Therefore, prevention and treatment of CNS symptoms may be necessary for the recovery of COVID-19 patients. Further, a database and laboratory-based study can be launched considering the genetic expression of various nervous system biomolecules to develop a clear insight into the correlation between psychological disorders and COVID-19. 
Author contributions: Concept - M.S.H., S.B.; Design - M.T.A., F.H., S.C.; Supervision -M.S.H.; Data Collection and/or Processing - M.T.A., S.C., H.D.; Analysis and/or Interpretation - M.T.A., H.D., F.H., S.B.; Literature Search - S.C., H.D., SB.; Writing - S.C., H.D., M.T.A.; Critical Reviews -S.C., H.D., M.T.A., S.B., F.H., M.S.H.

Conflict of interest statement: The authors declared no conflict of interest.

\section{REFERENCES}

[1] Thompson R. Pandemic potential of 2019-nCoV. Lancet Infect Dis. 2020; 20(3): 280. [CrossRef]

[2] WHO Director-General's opening remarks at the media briefing on COVID-19 - 8 January 2021. https://www.who.int/director-general/speeches/detail/who-director-general-s-opening-remarks-at-the-mediabriefing-on-covid-19-8-january-2021 (accessed January 8,2021)

[3] Xiang YT, Yang Y, Li W, Zhang L, Zhang Q, Cheung T, Ng CH. Timely mental health care for the 2019 novel coronavirus outbreak is urgently needed. Lancet Psychiatry. 2020; 7(3): 228-229. [CrossRef]

[4] Greenberg N, Docherty M, Gnanapragasam S, Wessely S. Managing mental health challenges faced by healthcare workers during covid-19 pandemic. BMJ. 2020; 368: m1211. [CrossRef]

[5] Xiao H, Zhang Y, Kong D, Li S, Yang N. Social capital and sleep quality in individuals who self-isolated for 14 days during the coronavirus disease 2019 (COVID-19) outbreak in January 2020 in China. Med Sci Monit. 2020; 26 : e923921. [CrossRef]

[6] Lai J, Ma S, Wang Y, Cai Z, Hu J, Wei N, et al. Factors Associated With Mental Health Outcomes Among Health Care Workers Exposed to Coronavirus Disease 2019. JAMA Netw open. 2020; 3(3): e203976. [CrossRef]

[7] Sher L. COVID-19, anxiety, sleep disturbances and suicide. Sleep Med. 2020; 70: 124. [CrossRef]

[8] Rajeswari S, Sanjeevareddy N. Efficacy of progressive muscle relaxation on pregnancy outcome among anxious indian primi mothers. Iran J Nurs Midwifery Res. 2020; 25(1): 23-30. [CrossRef]

[9] Liu S, Yang L, Zhang C, Xiang YT, Liu Z, Hu S, Zhang B. Online mental health services in China during the COVID19 outbreak. Lancet Psychiatry. 2020; 7(4): e17-e18. [CrossRef]

[10] Wang W, Song W, Xia Z, He Y, Tang L, Hou J, Lei S. Sleep Disturbance and Psychological Profiles of Medical Staff and Non-Medical Staff During the Early Outbreak of COVID-19 in Hubei Province, China. Front Psychiatry. 2020; 11: 733. [CrossRef]

[11] Zheng R, Zhou Y, Qiu M, Yan Y, Yue J, Yu L, Lei X, Tu D, Hu Y. Prevalence and associated factors of depression, anxiety, and stress among Hubei pediatric nurses during COVID-19 pandemic. Compr Psychiatry. 2021; 104: 152217.[CrossRef]

[12] Tan T, Khoo B, Mills EG, Phylactou M, Patel B, Eng PC, et al. Association between high serum total cortisol concentrations and mortality from COVID-19. Lancet Diabetes Endocrinol; 2020; 8(8): 659-660. [CrossRef]

[13] Zou L, Ruan F, Huang M, Liang L, Huang H, Hong Z, et al. SARS-CoV-2 Viral Load in Upper Respiratory Specimens of Infected Patients. N Engl J Med . 2020; 382(12): 1177-1179. [CrossRef]

[14] Miller AJ, Arnold AC. The renin-angiotensin system in cardiovascular autonomic control: recent developments and clinical implications. Clin Auton Res. 2019; 29(2): 231-243. [CrossRef]

[15] Wrapp D, Wang N, Corbett KS, Goldsmith JA, Hsieh C-L, Abiona O, et al. Cryo-EM Structure of the 2019-nCoV Spike in the Prefusion Conformation. Science. 2020; 367(6483): 1260-1263. [CrossRef]

[16] Baig AM, Khaleeq A, Ali U, Syeda H. Evidence of the COVID-19 Virus Targeting the CNS: Tissue Distribution, HostVirus Interaction, and Proposed Neurotropic Mechanisms. ACS Chem Neurosci. 2020; 11(7): 995-998. [CrossRef]

[17] Soria V, González-Rodríguez A, Huerta-Ramos E, Usall J, Cobo J, Bioque M, et al. Targeting hypothalamic-pituitaryadrenal axis hormones and sex steroids for improving cognition in major mood disorders and schizophrenia: a systematic review and narrative synthesis. Psychoneuroendocrinology. 2018; 93: 8-19. [CrossRef]

[18] Téblick A, Peeters B, Langouche L, Van den Berghe G. Adrenal function and dysfunction in critically ill patients. Nat Rev Endocrinol. 2019; 15(7): 417-427. [CrossRef]

[19] Khoo B, Boshier PR, Freethy A, Tharakan G, Saeed S, Hill N, et al. Redefining the stress cortisol response to surgery. Clin Endocrinol. 2017; 87(5): 451-458. [CrossRef]

[20] Ng Kee Kwong KC, Mehta PR, Shukla G, Mehta AR. COVID-19, SARS and MERS: A neurological perspective. J Clin Neurosci. 2020; 77: 13-16. [CrossRef] 
[21] Fries GR, Gassen NC, Rein T. The FKBP51 glucocorticoid receptor co-chaperone: Regulation, function, and implications in health and disease. Int J Mol Sci. 2017; 18(12): 2614. [CrossRef]

[22] Rein T. FK506 binding protein 51 integrates pathways of adaptation: FKBP51 shapes the reactivity to environmental change. Bioessays. 2018; 38(9): 894-902.[CrossRef]

[23] Grad I, Picard D. The glucocorticoid responses are shaped by molecular chaperones. Mol Cell Endocrinol; 2007; 275(12): 2-12. [CrossRef]

[24] Nair SC, Rimerman RA, Toran EJ, Chen S, Prapapanich V, Butts RN, et al. Molecular cloning of human FKBP51 and comparisons of immunophilin interactions with Hsp90 and progesterone receptor. Mol Cell Biol. 1997; 17(2): 594603. [CrossRef]

[25] Wochnik GM, Rüegg J, Abel GA, Schmidt U, Holsboer F, Rein T. FK506-binding proteins 51 and 52 differentially regulate dynein interaction and nuclear translocation of the glucocorticoid receptor in mammalian cells. J Biol Chem. 2005; 280(6): 4609-4616. [Crossref]

[26] Zhang X, Clark AF, Yorio T. FK506-binding protein 51 regulates nuclear transport of the glucocorticoid receptor $\beta$ and glucocorticoid responsiveness. Investig Ophthalmol Vis Sci. 2008; 49(3): 1037-1047. [CrossRef]

[27] Pariante CM, Miller AH. Glucocorticoid receptors in major depression: Relevance to pathophysiology and treatment. Biol Psychiatry. 2001; 49(5): 391-404. [CrossRef]

[28] Isaksson J, Comasco E, Åslund C, Rehn M, Tuvblad C, Andershed H, et al. Associations between the FKBP5 haplotype, exposure to violence and anxiety in females. Psychoneuroendocrinology. 2016; 72: 196-204. [CrossRef]

[29] Mao L, Jin H, Wang M, Hu Y, Chen S, He Q, et al. Neurologic Manifestations of Hospitalized Patients with Coronavirus Disease 2019 in Wuhan, China. JAMA Neurol. 2020; 77(6): 683-690. [CrossRef]

[30] Asadi-Pooya AA, Simani L. Central nervous system manifestations of COVID-19: A systematic review. J Neurol Sci. 2020; 413: 116832. [CrossRef]

[31] Moro E, Priori A, Beghi E, Helbok R, Campiglio L, Bassetti CL, et al. The international European Academy of Neurology survey on neurological symptoms in patients with COVID-19 infection. Eur J Neurol. 2020; 27(9): 17271737. [CrossRef]

[32] Zhou F, Yu T, Du R, Fan G, Liu Y, Liu Z, et al. Clinical course and risk factors for mortality of adult inpatients with COVID-19 in Wuhan, China: a retrospective cohort study. Lancet. 2020; 395(10229): 1054-1062. [CrossRef]

[33] Pinto JA, Ribeiro DK, Da Silva Cavallini AF, Duarte C, Freitas GS. Comorbidities associated with obstructive sleep apnea: A retrospective study. Int Arch Otorhinolaryngol. 2016; 20(2): 145-150. [CrossRef]

[34] Chen N, Zhou M, Dong X, Qu J, Gong F, Han Y, et al. Epidemiological and clinical characteristics of 99 cases of 2019 novel coronavirus pneumonia in Wuhan, China: a descriptive study. Lancet. 2020; 395(10223): 507-513. [CrossRef]

[35] Hamming I, Timens W, Bulthuis MLC, Lely AT, Navis GJ, van Goor H. Tissue distribution of ACE2 protein, the functional receptor for SARS coronavirus. A first step in understanding SARS pathogenesis. J Pathol. 2004; 203(2): 631-637. [CrossRef]

[36] Huang C, Wang Y, Li X, Ren L, Zhao J, Hu Y, et al. Clinical features of patients infected with 2019 novel coronavirus in Wuhan, China. Lancet. 2020; 395(10223): 497-506. [CrossRef]

[37] Cowley TJ, Weiss SR. Murine coronavirus neuropathogenesis: Determinants of virulence. J Neurovirol. 2010; 16(6): 427-434. [CrossRef]

[38] Futch HS, Croft CL, Truong VQ, Krause EG, Golde TE. Targeting psychologic stress signaling pathways in Alzheimer's disease. Mol Neurodegener. 2017; 12(1): 49. [CrossRef]

[39] Sanders J, Nemeroff C. The CRF System as a Therapeutic Target for Neuropsychiatric Disorders. Trends Pharmacl Sci. 2016; 37(12): 1045-1054. [CrossRef]

[40] Gunnar M, Quevedo K. The neurobiology of stress and development. Annu Rev Psychol . 2007; 58: 145-173. [CrossRef]

[41] Arborelius L, Owens MJ, Plotsky PM, Nemeroff CB. The role of corticotropin-releasing factor in depression and anxiety disorders.J Endocrinol; 1999; 160(1): 1-12. [CrossRef]

[42] Radley JJ, Williams B, Sawchenko PE. Noradrenergic innervation of the dorsal medial prefrontal cortex modulates hypothalamo-pituitary-adrenal responses to acute emotional stress. J Neurosci. 2008; 28(22): 5806-5816. [CrossRef]

[43] Buckley TM, Schatzberg AF. On the interactions of the hypothalamic-pituitary-adrenal (HPA) axis and sleep: Normal HPA axis activity and circadian rhythm, exemplary sleep disorders. J Clin Endocrinol Metab. 2005; 90(5): 3106-3114. 
[CrossRef]

[44] Dhabhar FS. Effects of stress on immune function: The good, the bad, and the beautiful. Immunol Res. 2014; 58(2-3): 193-210. [CrossRef]

[45] Bryant PA, Trinder J, Curtis N. Sick and tired: Does sleep have a vital role in the immune system?. Nat Rev Immunol. 2004; 4(6): 457-467. [CrossRef]

[46] Shearer WT, Reuben JM, Mullington JM, Price NJ, Lee BN, O'brian Smith E, et al. Soluble TNF-a receptor 1 and IL-6 plasma levels in humans subjected to the sleep deprivation model of spaceflight. J Allergy Clin Immunol. 2001; 107(1): 165-170. [CrossRef]

[47] Lange T, Dimitrov S, Born J. Effects of sleep and circadian rhythm on the human immune system. Ann N Y Acad Sci. 2010; 1193: 48-59. [CrossRef]

[48] Tan H-L, Kheirandish-Gozal L, Gozal D. Sleep, Sleep Disorders, and Immune Function. In: Fishbein A, Sheldon S. (Eds). Allergy and Sleep. Springer, Cham. 2019, pp. 3-15. [CrossRef]

[49] Palmblad J, Cantell K, Strander H, Fröberg J, Karlsson CG, Levi L, et al. Stressor exposure and immunological response in man: Interferon-producing capacity and phagocytosis. J Psychosom Res. 1976; 20(3): 193-199. [CrossRef]

[50] Said EA, Al-Abri MA, Al-Saidi I, Al-Balushi MS, Al-Busaidi JZ, Al-Reesi I, et al. Sleep deprivation alters neutrophil functions and levels of Th1-related chemokines and CD4+ T cells in the blood. Sleep Breath. 2019; 23(4): 1331-1339. [CrossRef]

[51] Spiegel K. Effect of Sleep Deprivation on Response to Immunizaton. J Am Med Assoc. 2002; 288(12): 1471-1472. [CrossRef]

[52] Lange T, Perras B, Fehm HL, Born J. Sleep enhances the human antibody response to hepatitis A vaccination. Psychosom Med. 2003; 65(5): 831-835. [CrossRef]

[53] Everson CA. Sustained sleep deprivation impairs host defense. Am J Physiol. 1993; 65(5 Pt 2): R1148-R1154. [CrossRef]

[54] Ramanathan L, Gulyani S, Nienhuis R, Siegel JM. Sleep deprivation decreases superoxide dismutase activity in rat hippocampus and brainstem. Neuroreport. 2002; 13(11): 1387-1390. [CrossRef]

[55] Teixeira KRC, dos Santos CP, de Medeiros LA, Mendes JA, Cunha TM, De Angelis K, et al. Night workers have lower levels of antioxidant defenses and higher levels of oxidative stress damage when compared to day workers. Sci Rep. 2019; 9(1): 4455. [CrossRef]

[56] Hajak G, Rodenbeck A, Staedt J, Bandelow B, Huether G, Rüther E. Nocturnal plasma melatonin levels in patients suffering from chronic primary insomnia. J Pineal Res. 1995; 19(3): 116-122. [CrossRef]

[57] McGiffin JN, Galatzer-Levy IR, Bonanno GA. Is the intensive care unit traumatic? What we know and don't know about the intensive care unit and post-traumatic stress responses. Rehabil Psychol. 2016; 61(2): 120-131. [CrossRef]

[58] Bo HX, Li W, Yang Y, Wang Y, Zhang Q, Cheung T, et al. Post-traumatic stress symptoms and attitude toward crisis mental health services among clinically stable patients with COVID-19 in China. Psychol Med. 2021; 51(6): 1052-1053. [CrossRef]

[59] Aardema F, Wong SF. Feared possible selves in cognitive-behavioral theory: An analysis of its historical and empirical context, and introduction of a working model. J Obsess-compuls Rel. 2020; 24: 100479. [CrossRef]

[60] Di Fusco SA, Pignalberi C, Santini L, Colivicchi F, Santini M. Arrhythmias and sleep apnea: physiopathologic link and clinical implications. J Interv Card Electrophysiol. 2020; 57(3): 387-397. [CrossRef]

[61] Wu CI, Postema PG, Arbelo E, Behr ER, Bezzina CR, Napolitano C, et al. SARS-CoV-2, COVID-19, and inherited arrhythmia syndromes. Hear Rhythm. 2020; 17(9): 1456-1462. [CrossRef]

[62] Khawam E, Khouli H, Pozuelo L. Treating acute anxiety in patients with COVID-19. Cleve Clin J Med. 2020. [CrossRef]

[63] Duarte RLM, Magalhães-Da-silveira FJ, Oliveira-E-sá TS, Silva JA, Mello FCQ, Gozal D. Obstructive sleep apnea screening with a 4-item instrument, named GOAL questionnaire: Development, validation and comparative study with no-apnea, STOP-bang, and NoSAS. Nat Sci Sleep. 2020; 12: 57-67. [CrossRef] 